\title{
A catalyst-free multicomponent domino sequence for the diastereoselective synthesis of (E)-3-[2-aryl- carbonyl-3-(arylamino)allyl]chromen-4-ones
}

\author{
Pitchaimani Prasanna ${ }^{1}$, Pethaiah Gunasekaran ${ }^{1}$, Subbu Perumal ${ }^{* 1}$ \\ and J. Carlos Menéndez ${ }^{*}$
}

Open Access

\author{
Full Research Paper \\ Address: \\ ${ }^{1}$ Department of Organic Chemistry, School of Chemistry, Madurai \\ Kamaraj University, Madurai - 625 021, Tamilnadu, India and \\ ${ }^{2}$ Departamento de Química Orgánica and Farmacéutica, Facultad de \\ Farmacia, Universidad Complutense, 28040 Madrid, Spain \\ Email: \\ Subbu Perumal ${ }^{*}$ - subbu.perum@gmail.com; J. Carlos Menéndez* - \\ josecm@farm.ucm.es \\ ${ }^{*}$ Corresponding author \\ Keywords: \\ chromones; domino reactions; Michael additions; multicomponent \\ reactions; transfer hydrogenation
}

\begin{abstract}
Beilstein J. Org. Chem. 2014, 10, 459-465. doi:10.3762/bjoc. 10.43
\end{abstract}

Received: 29 October 2013

Accepted: 21 January 2014

Published: 21 February 2014

This article is part of the Thematic Series "Multicomponent reactions II".

Guest Editor: T. J. J. Müller

(C) 2014 Prasanna et al; licensee Beilstein-Institut.

License and terms: see end of document.

\begin{abstract}
The three-component domino reactions of (E)-3-(dimethylamino)-1-arylprop-2-en-1-ones, 3-formylchromone and anilines under catalyst-free conditions afforded a library of novel (E)-3-(2-arylcarbonyl-3-(arylamino)allyl)-4H-chromen-4-ones in good to excellent yields and in a diastereoselective transformation. This transformation generates one $\mathrm{C}-\mathrm{C}$ and one $\mathrm{C}-\mathrm{N}$ bond and presumably proceeds via a reaction sequence comprising a Michael-type addition-elimination reaction, a nucleophilic attack of an enamine to a carbonyl reminiscent of one of the steps of the Bayllis-Hilman condensation, and a final deoxygenation. The deoxygenation is assumed to be induced by carbon monoxide resulting from the thermal decomposition of the dimethylformamide solvent.
\end{abstract}

\section{Introduction}

Chromones are widely present in nature, especially in the plant kingdom, and a wide variety of useful biological properties are associated with them $[1,2]$. Chromone derivatives act as effective tyrosine and protein kinase $\mathrm{C}$ inhibitors [3] and display antifungal [4,5], antimycobacterial [6], antiviral [7], antihypertensive [8], anti-oxidant [9-12], HIV-inhibitory [13], antiinflammatory $[14,15]$, immunomodulatory [16], antithrombotic
[17], and anticancer [18-20] activities. Furthermore, some chromone derivatives have been identified as suitable fluorophores for live cell imaging [21]. In view of its importance chromone has emerged as a pharmacophore in drug discovery programmes, leading to several drugs in the market (e.g. cromolyn and nedocromil) and thereby continuing to draw the attention of synthetic organic and medicinal chemists [22- 
24]. However, there are relatively few methods, which allow the preparation of hybrid structures containing chromone derivatives attached to other heterocyclic systems due to the lack of suitable building blocks. In order to come up with such building blocks, we planned the preparation of chromones containing a $\beta$-enaminone structural fragment, since enaminones are versatile starting materials in organic synthesis and are notably important for the synthesis of nitrogen heterocycles [25-27]. In particular, $\beta$-enaminoketones are endowed with electrophilic and nucleophilic reaction centers and have a versatile reactivity that allows their application in the synthesis of important heterocycles such as indole [28], dihydropyridine [29], quinoline [30], pyrrole [31] and pyridinone [32]. Furthermore, they can take part in one-pot multicomponent reactions with both nucleophilic and electrophilic reactants, leading to a fast access to structurally diverse carbocycles and heterocycles, an area in which we have recently become interested [33-42]. Thus, the present study ia a continuation of our research program on the construction of novel heterocycles employing one-pot green domino-multicomponent transformations [43-54].

In order to achieve our goal, we embarked on the study of the three-component reactions between 3-formylchromone (1), $(E)$ 3-(dimethylamino)-1-arylprop-2-en-1-ones $\mathbf{2}$ and anilines $\mathbf{3}$, which we expected to furnish novel (E)-3-[2-arylcarbonyl-3(arylamino)allyl]-4H-chromen-4-ones 5 comprising the desired chromonone and $\beta$-enaminoketone moieties via intermediate species 4 . The overall synthetic strategy is summarized in Scheme 1.

\section{Results and Discussion}

We started our study with the optimization of a model reaction between 3-formylchromone (1, $1 \mathrm{mmol}),(E)$-3-(dimethylamino)-1-(3-nitrophenyl)prop-2-en-1-one $(1 \mathrm{mmol})$ and 4-methoxyaniline $(1 \mathrm{mmol})$. This three-component reaction was initially examined in solvents such as acetonitrile, dioxane, dimethyl sulfoxide, toluene and ethanol under heating.
However, the only isolable product was compound $\mathbf{4 d}$, which originated from a reaction between the last two components without participation of the chromone substrate (Table 1, entries $1-5)$. The use of dimethylformamide as a solvent, on the other hand, allowed the isolation of the target (E)-3-[3-(4-methoxyphenylamino]-2-(3-nitrobenzoyl)allyl)-4H-chromen-4-one (5f). After temperature fine-tuning (Table 1, entries 6-11), we identified heating in DMF at $130{ }^{\circ} \mathrm{C}$ for $6 \mathrm{~h}$ as the optimal conditions, which afforded $\mathbf{5 f}$ in $94 \%$ yield (Table 1, entry 11).

\begin{tabular}{|c|c|c|c|c|}
\hline & 4d & & $0^{\prime}$ & $\begin{array}{l}- \\
\mathrm{O}_{2}\end{array}$ \\
\hline Entry & Solvent & Time (h) & Temp. $\left({ }^{\circ} \mathrm{C}\right)$ & Yield (\%) \\
\hline 1 & $\mathrm{CH}_{3} \mathrm{CN}$ & 12 & 80 & $-{ }^{b}$ \\
\hline 2 & dioxane & 10 & 102 & $-^{b}$ \\
\hline 3 & DMSO & 10 & 140 & $-{ }^{b}$ \\
\hline 4 & toluene & 10 & 110 & $-{ }^{b}$ \\
\hline 5 & $\mathrm{EtOH}$ & 10 & 78 & $-b$ \\
\hline 6 & DMF & 6 & 60 & 27 \\
\hline 7 & DMF & 6 & 80 & 34 \\
\hline 8 & DMF & 6 & 100 & 43 \\
\hline 9 & DMF & 6 & 110 & 61 \\
\hline 10 & DMF & 6 & 120 & 74 \\
\hline 11 & DMF & 6 & 130 & 94 \\
\hline
\end{tabular}

asolated yield after purification by column chromatography. ${ }^{b}$ Compound $\mathbf{4 d}$ was obtained predominantly.

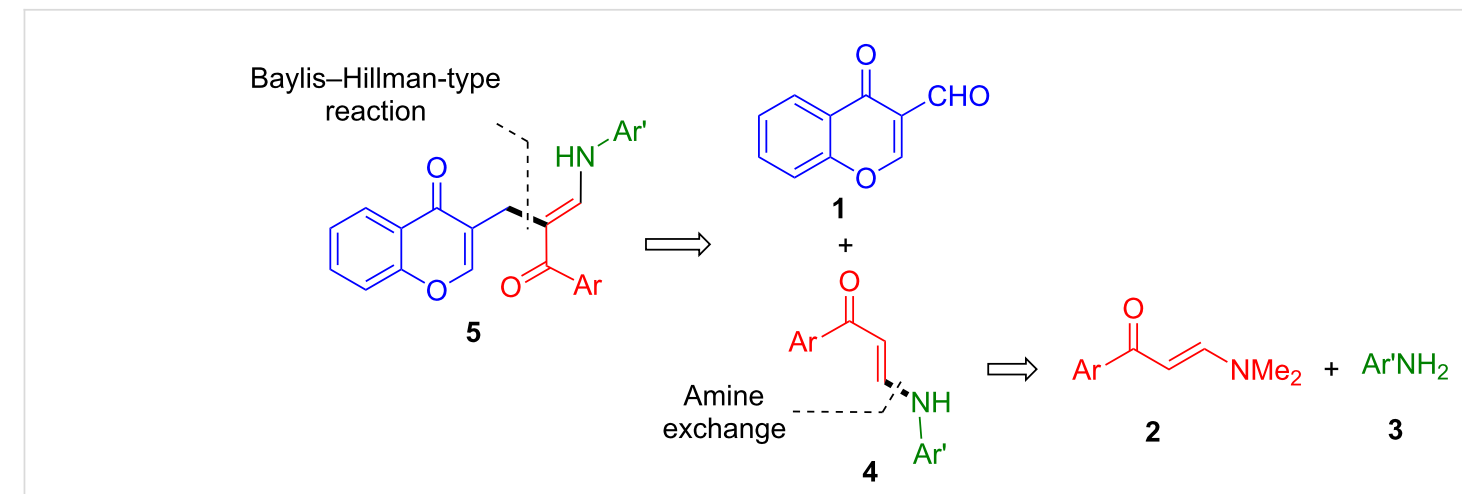


All the subsequent reactions of 3-formylchromone (1), $(E)$-3(dimethylamino)-1-arylprop-2-en-1-ones 2 and substituted anilines 3 were performed under the optimal conditions (equimolecular amounts, DMF at $130{ }^{\circ} \mathrm{C}$ ) and were completed in 6-7 h. After completion of the reaction, removal of the solvent and purification of the residue by column chromatography, (E)-3-[2-arylcarbonyl-3-(arylamino)allyl]-4H-chromen4 -ones 5 were obtained in pure form in $78-94 \%$ yields (Scheme 2 and Table 2). It is noteworthy, that a similar reaction, in which the less hindered, more reactive formaldehyde was employed as the aldehyde component, took a completely divergent course and afforded 5-arylcarbonyl-1,3-diarylhexahydropyrimidines arising from pseudo five-component reactions of (E)-3-(dimethylamino)-1-arylprop-2-en-1-ones, two molecules of formaldehyde and two molecules of aniline [55].

The structure of compounds 5 was deduced from one and twodimensional NMR spectroscopic data, as detailed in Supporting Information File 1 for $\mathbf{5 h}$ as a representative example. The structure of $\mathbf{5 h}$ deduced from the NMR spectroscopic studies was subsequently confirmed by single-crystal X-ray crystallographic data, as shown in Figure 1 [56].

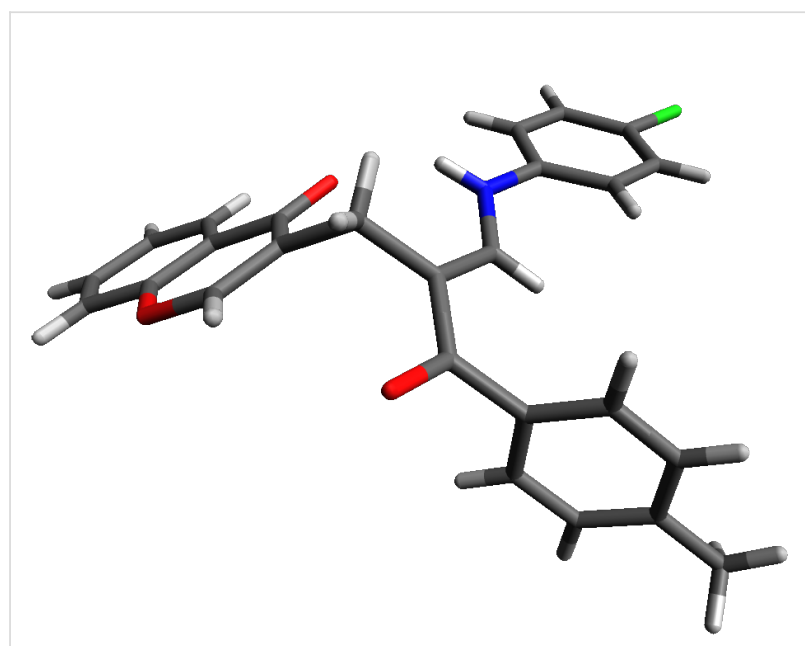

Figure 1: X-ray structure of compound $5 \mathrm{~h}$.

Scheme 2: Synthesis of compounds 5 .

\begin{tabular}{|c|c|c|c|c|c|}
\hline Entry & Comp. & $\mathrm{Ar}$ & $A r^{\prime}$ & Time (h) & Yield $(\%)^{a}$ \\
\hline 1 & $5 a$ & $\mathrm{C}_{6} \mathrm{H}_{5}$ & $4-\mathrm{MeC}_{6} \mathrm{H}_{4}$ & 6 & 85 \\
\hline 2 & $5 b$ & $4-\mathrm{ClC}_{6} \mathrm{H}_{4}$ & $4-\mathrm{MeC}_{6} \mathrm{H}_{4}$ & 6 & 87 \\
\hline 3 & $5 c$ & $3-\mathrm{NO}_{2} \mathrm{C}_{6} \mathrm{H}_{4}$ & $4-\mathrm{MeC}_{6} \mathrm{H}_{4}$ & 6 & 90 \\
\hline 4 & $5 d$ & $\mathrm{C}_{6} \mathrm{H}_{5}$ & $4-\mathrm{MeOC}_{6} \mathrm{H}_{4}$ & 6 & 89 \\
\hline 5 & $5 e$ & $4-\mathrm{ClC}_{6} \mathrm{H}_{4}$ & 4- $\mathrm{MeOC}_{6} \mathrm{H}_{4}$ & 6 & 91 \\
\hline 6 & $5 f$ & $3-\mathrm{NO}_{2} \mathrm{C}_{6} \mathrm{H}_{4}$ & $4-\mathrm{MeOC}_{6} \mathrm{H}_{4}$ & 6 & 94 \\
\hline 7 & $5 g$ & $4-\mathrm{ClC}_{6} \mathrm{H}_{4}$ & $4-\mathrm{ClC}_{6} \mathrm{H}_{4}$ & 6 & 86 \\
\hline 8 & $5 h$ & $4-\mathrm{MeC}_{6} \mathrm{H}_{4}$ & $4-\mathrm{ClC}_{6} \mathrm{H}_{4}$ & 7 & 84 \\
\hline 9 & $5 i$ & $4-\mathrm{MeOC}_{6} \mathrm{H}_{4}$ & $4-\mathrm{ClC}_{6} \mathrm{H}_{4}$ & 7 & 82 \\
\hline 10 & $5 j$ & $3-\mathrm{NO}_{2} \mathrm{C}_{6} \mathrm{H}_{4}$ & $4-\mathrm{ClC}_{6} \mathrm{H}_{4}$ & 6 & 87 \\
\hline 11 & $5 k$ & $\mathrm{C}_{6} \mathrm{H}_{5}$ & $4-\mathrm{BrC}_{6} \mathrm{H}_{4}$ & 6 & 80 \\
\hline 12 & $5 I$ & $4-\mathrm{MeC}_{6} \mathrm{H}_{4}$ & $4-\mathrm{BrC}_{6} \mathrm{H}_{4}$ & 6 & 81 \\
\hline 13 & $5 \mathrm{~m}$ & $4-\mathrm{MeC}_{6} \mathrm{H}_{4}$ & $4-\mathrm{FC}_{6} \mathrm{H}_{4}$ & 7 & 83 \\
\hline 14 & $5 n$ & $4-\mathrm{MeC}_{6} \mathrm{H}_{4}$ & $3-\mathrm{NO}_{2} \mathrm{C}_{6} \mathrm{H}_{4}$ & 7 & 78 \\
\hline 15 & 50 & $4-\mathrm{ClC}_{6} \mathrm{H}_{4}$ & $\mathrm{C}_{6} \mathrm{H}_{5}$ & 6 & 86 \\
\hline 16 & $5 p$ & $3-\mathrm{NO}_{2} \mathrm{C}_{6} \mathrm{H}_{4}$ & $\mathrm{C}_{6} \mathrm{H}_{5}$ & 6 & 88 \\
\hline
\end{tabular}

alsolated yield after purification by column chromatography. 
Our initial mechanistic hypothesis accounting for the formation of compounds 5 is depicted in Scheme 3. An initial Michael addition-elimination reaction, leading to the exchange between the starting arylamine $\mathbf{3}$ and dimethylamine, explains the formation of intermediates 4 , which were the final reaction products in most investigated solvents. However, in DMF, the enamine moiety of $\mathbf{4}$ attacks the aldehyde group in $\mathbf{1}$ giving rise to 6 . This reaction resembles one of the steps of the Bayllis-Hilman condensation and is presumably promoted by the presence of traces of formic acid as a contaminant of the solvent [57].

We established the feasibility of the first step by showing that the reaction between two of our starting enaminones, namely $\mathbf{2 a}$ $(\mathrm{Ar}=\mathrm{Ph})$ and $2 \mathrm{c}\left(\mathrm{Ar}=3-\mathrm{NO}_{2} \mathrm{C}_{6} \mathrm{H}_{4}\right)$ with aniline under our standard reaction conditions (DMF, $130{ }^{\circ} \mathrm{C}$ ) affords the corresponding compounds 4 after $3 \mathrm{~h}$ in $94 \%$ and $90 \%$ yields, respectively. As previously mentioned (Table 1), the nature of the solvent was found to be of critical importance, and the transformation of intermediate $\mathbf{4}$ into the final products $\mathbf{5}$ was found to work only in DMF, among many investigated solvents. Since the reaction between $\mathbf{4}$ and $\mathbf{1}$ is proposed to be catalyzed by acid, we carried out the multicomponent reaction in a selection of solvents (dioxane, acetonitrile, dimethyl sulfoxide, ethanol, ethylene glycol) in the presence of one equivalent of $\mathrm{HCl}$, but all these attempts failed, while the same conditions were successful in DMF. These results can be explained by assuming that the initial aldol-type reaction between $\mathbf{1}$ and $\mathbf{4}$ to give $\mathbf{6}$ is reversible and is driven to completion by the reduction step, which takes place in DMF only. Thus, interestingly, the reaction does not stop at compound $\mathbf{6}$, but instead undergoes a reductive termination step, which leads to the final products $\mathbf{5}$.
This reduction step is intriguing, and a first mechanistic possibility could be a hydride transfer from formate anion. While this mechanism might partly account for the observed reduction, we acknowledge that it is problematic to rely on solvent impurities to account for a stoichiometric reduction. Alternatively, dimethylformamide itself might have been the reducing agent. There are a few scattered literature reports on the use of DMF as a reducing agent, the first of which seems to be the reduction of diazonium tetrafluoroborate salts to arenes [58]. DMF has also been described as a reducing agent acting by hydride transfer in Pd-catalyzed processes, where the metal plays a critical role in the reduction by decomposing it and facilitating hydride transfer from a Pd intermediate [59-61]. However, it is not clear whether the same type of reaction may take place under our conditions. In order to test this ideas experimentally, we carried out the reaction between 3-formylchromone (1), $(E)$ 3-(dimethylamino)-1-(4-chlorophenyl)prop-2-en-1-one and $p$-toluidine in DMF- $d_{7}$. If the mechanistic hypothesis was correct, this reaction should lead to a $d-7$ intermediate and hence to a mixture of $\mathbf{5}$ and $d-\mathbf{5}$, with the latter being major due to isotope effects in the tautomeric equilibrium. However, this reaction failed to show any incorporation of deuterium into $\mathbf{5}$, and therefore we had to abandon the hydride-transfer hypothesis.

We came up with an alternative explanation based on the wellknown fact that DMF decomposes into dimethylamine and carbon monoxide at its boiling point. Carbon monoxide can act as a deoxygenating agent [62] and thus explain the transformation of $\mathbf{6}$ into 5 as shown in Scheme 4. Because of the synthetic interest of allylic and benzylic deoxygenations, further research into this reaction is under way in our laboratories.

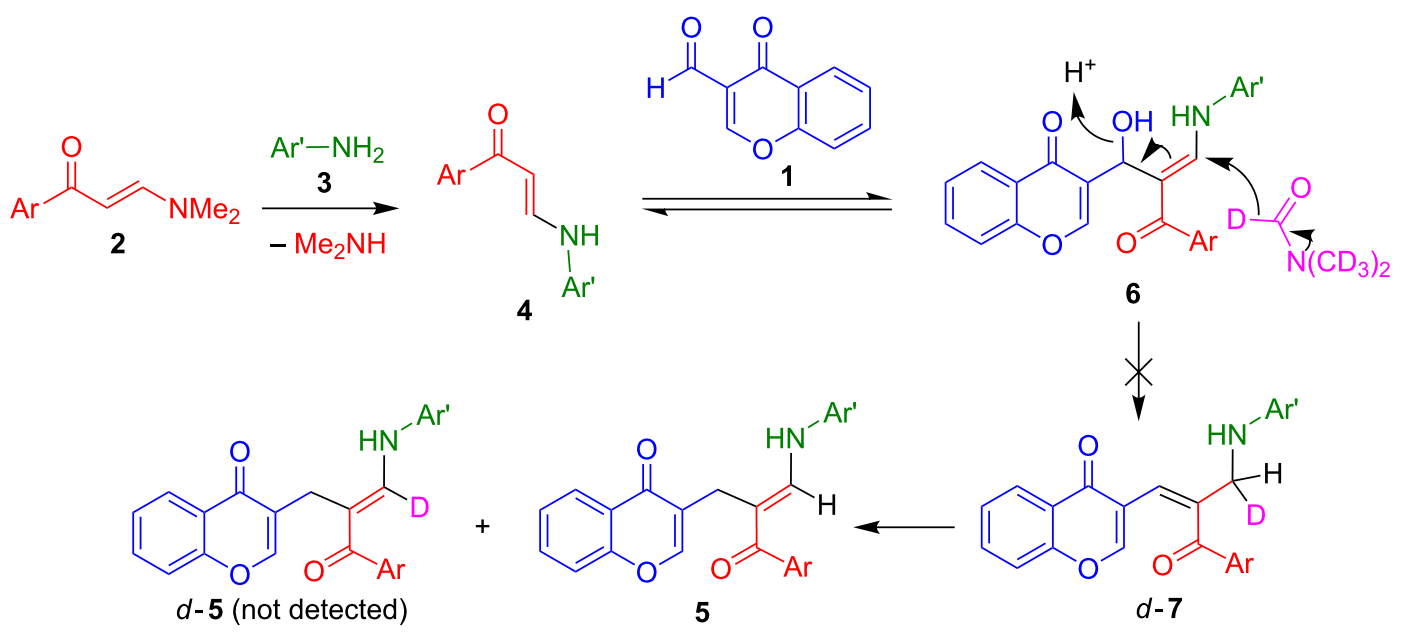




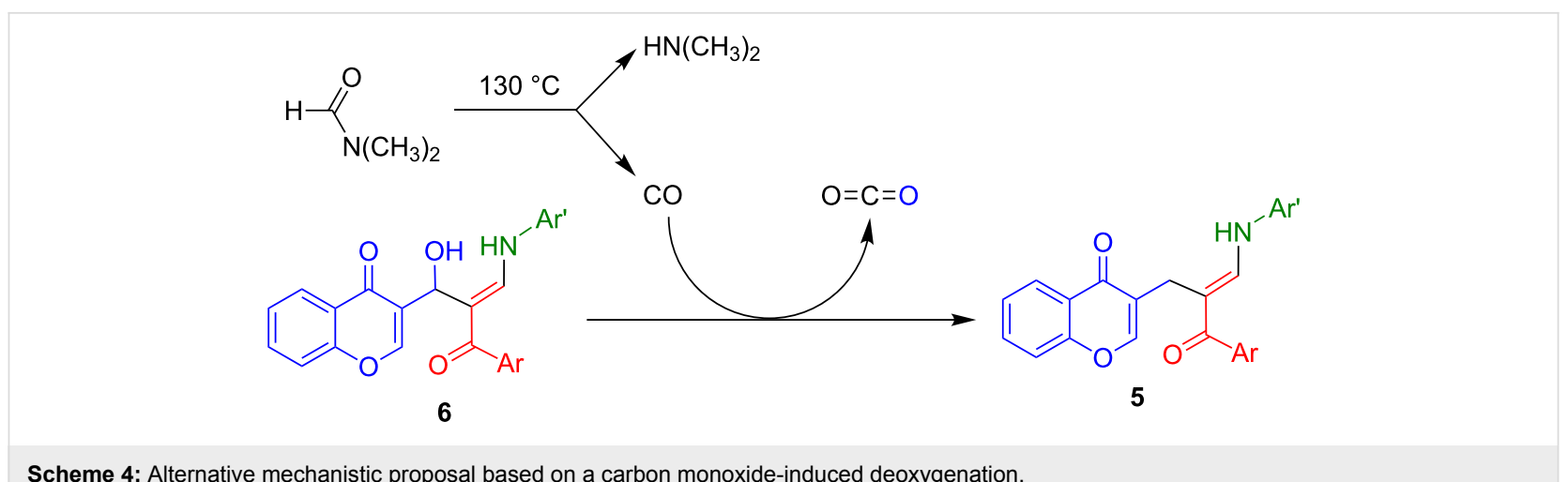

Scheme 4: Alternative mechanistic proposal based on a carbon monoxide-induced deoxygenation.

\section{Conclusion}

We have developed a facile three-component diastereoselective synthesis of novel (E)-3-[2-arylcarbonyl-3-(arylamino)allyl]$4 H$-chromen-4-ones containing chromone and $\beta$-enaminoketone structural fragments from simple, readily available starting materials in a one-pot operation and in good to excellent yields. This transformation occurs via a domino sequence of reactions, which generates one $\mathrm{C}-\mathrm{C}$ and one $\mathrm{C}-\mathrm{N}$ bond. Presumably, this transformation proceeds via a reaction sequence comprising a Michael-type addition-elimination reaction, a nucleophilic attack of an enamine to a carbonyl, and a final deoxygenation step. We propose that the deoxygenation step is induced by carbon monoxide resulting from thermal decomposition of the dimethylformamide solvent.

\section{Experimental}

General methods. Melting points were measured in open capillary tubes and are uncorrected. The ${ }^{1} \mathrm{H}$ NMR, ${ }^{13} \mathrm{C}$ NMR, DEPT, $\mathrm{H}, \mathrm{H}-\mathrm{COSY}, \mathrm{C}, \mathrm{H}-\mathrm{COSY}$ and HMBC spectra were recorded on a Bruker (Avance) $300 \mathrm{MHz}$ NMR instrument by using TMS as an internal standard and $\mathrm{CDCl}_{3}$ as a solvent. Standard Bruker software was used throughout. Chemical shifts are given in parts per million ( $\delta$-scale), and the coupling constants are given in Hertz. Silica gel-G plates (Merck) were used for TLC analysis with a mixture of petroleum ether $\left(60-80{ }^{\circ} \mathrm{C}\right)$ and ethyl acetate as an eluent. Elemental analyses were performed on a Perkin Elmer 2400 Series II Elemental CHNS analyzer.

General procedure for the synthesis of $(E)-3-(2-a r y l-$ carbonyl-3-(arylamino)allyl)-4H-chromen-4-one derivatives 5a-5p. In a similar manner as described in [55], a mixture of 3-formylchromone (1, $1 \mathrm{mmol})$, enaminone 2 (1 mmol) and aniline $3(1 \mathrm{mmol})$ in DMF $(5 \mathrm{~mL})$ was heated at $130{ }^{\circ} \mathrm{C}$ for 6-7 $\mathrm{h}$. The reaction progress was monitored by TLC. After completion of the reaction, the solvent was removed and the product was purified by column chromatography with a petroleum ether-ethyl acetate mixture $(4: 1 \mathrm{v} / \mathrm{v})$ as an eluent to afford compounds 5. Characterization data for representative com- pounds are given below. The characterization data for the full library can be found in Supporting Information File 1.

(E)-3-(2-Benzoyl-3-(p-tolylamino)allyl)-4H-chromen-4-one (5a): Isolated yield $0.336 \mathrm{~g}(85 \%)$; colorless solid; $\mathrm{mp}$ 215-216 ${ }^{\circ} \mathrm{C} ;{ }^{1} \mathrm{H} \mathrm{NMR}\left(300 \mathrm{MHz}, \mathrm{CDCl}_{3}, \delta, \mathrm{ppm}\right) 2.28(\mathrm{~s}, 3 \mathrm{H})$, $3.71(\mathrm{~s}, 2 \mathrm{H}), 6.92(\mathrm{~d}, J=8.4 \mathrm{~Hz}, 2 \mathrm{H}), 7.08(\mathrm{~d}, J=8.1 \mathrm{~Hz}, 2 \mathrm{H})$, 7.37-7.45 (m, 4H), 7.47-7.56 (m, 4H), 7.66-7.71 (m, 1H), 8.31 (d, $J=7.8 \mathrm{~Hz}, 1 \mathrm{H}), 8.52(\mathrm{~s}, 1 \mathrm{H}), 9.93(\mathrm{~d}, J=12.6 \mathrm{~Hz}, 1 \mathrm{H})$; ${ }^{13} \mathrm{C}$ NMR (75 MHz, $\left.\mathrm{CDCl}_{3}, \delta, \mathrm{ppm}\right): 20.1,20.6,113.3,115.8$, $118.3,123.7,123.9,125.0,125.9,128.0,128.5,129.8,130.1$, 132.3, 133.7, 138.9, 140.9, 146.6, 156.2, 156.7, 179.8, 195.0; HRMS-ESI $(\mathrm{m} / \mathrm{z})$ : $[\mathrm{M}-\mathrm{H}]^{-}$calcd for $\mathrm{C}_{26} \mathrm{H}_{20} \mathrm{NO}_{3}, 394.14432$; found, 394.144817; Anal. calcd for $\mathrm{C}_{26} \mathrm{H}_{21} \mathrm{NO}_{3}$ : C, 78.97; $\mathrm{H}$, 5.35; N, 3.54; found: C, 79.02; H, 5.29; N, 3.62.

(E)-3-(2-(3-Nitrobenzoyl)-3-(p-tolylamino)allyl)-4H-chromen4-one (5c): Isolated yield $0.396 \mathrm{~g}(90 \%)$; yellow solid; $\mathrm{mp}$ 206-207 ${ }^{\circ} \mathrm{C} ;{ }^{1} \mathrm{H} \mathrm{NMR}\left(300 \mathrm{MHz}, \mathrm{CDCl}_{3}, \delta, \mathrm{ppm}\right) 2.32$ (s, 3H), $3.72(\mathrm{~s}, 2 \mathrm{H}), 6.93(\mathrm{~d}, J=8.4 \mathrm{~Hz}, 2 \mathrm{H}), 7.10(\mathrm{~d}, J=8.1 \mathrm{~Hz}, 2 \mathrm{H})$, $7.40-753(\mathrm{~m}, 3 \mathrm{H}), 7.59$ (d, $J=8.0 \mathrm{~Hz}, 1 \mathrm{H}), 7.68-7.74(\mathrm{~m}, 1 \mathrm{H})$, $7.81(\mathrm{~d}, J=7.5 \mathrm{~Hz}, 1 \mathrm{H}), 8.28-8.35(\mathrm{~m}, 3 \mathrm{H}), 8.51(\mathrm{~s}, 1 \mathrm{H}), 10.2$ $(\mathrm{d}, J=12.6 \mathrm{~Hz}, 1 \mathrm{H}) ;{ }^{13} \mathrm{C} \mathrm{NMR}\left(75 \mathrm{MHz}, \mathrm{CDCl}_{3}, \delta, \mathrm{ppm}\right) 20.1$, 20.7, 113.0, 116.2, 118.4, 123.3, 123.6, 123.7, 124.4, 125.2, $125.9,129.2,130.2,133.1,133.9,134.1,138.4,142.5,147.3$, 148.0, 156.1, 156.7, 179.9, 191.8; HRMS-ESI $(m / z):[\mathrm{M}-\mathrm{H}]^{-}$ calcd for $\mathrm{C}_{26} \mathrm{H}_{19} \mathrm{~N}_{2} \mathrm{O}_{5}$, 439.12940; found, 439.12995; Anal. calcd for $\mathrm{C}_{26} \mathrm{H}_{20} \mathrm{~N}_{2} \mathrm{O}_{5}$ : C, 70.90; H, 4.58; N, 6.36; found: C, $70.84 ; \mathrm{H}, 4.62 ; \mathrm{N}, 6.29$.

\section{(E)-3-(3-(4-Chlorophenylamino)-2-(4-methylbenzoyl)allyl)-}

4H-chromen-4-one (5h): Isolated yield $0.361 \mathrm{~g}$ (84\%); colorless solid; mp 219-220 ${ }^{\circ} \mathrm{C} ;{ }^{1} \mathrm{H}$ NMR $\left(300 \mathrm{MHz}, \mathrm{CDCl}_{3}, \delta\right.$, ppm) 2.40 (s, 3H), $3.70(\mathrm{~s}, 2 \mathrm{H}), 6.95$ (d, $J=8.7 \mathrm{~Hz}, 2 \mathrm{H})$, 7.19-7.26 (m, 4H), 7.40-7.46 (m, 3H), 7.48-7.52 (m, 2H), 7.69 (t, $J=7.1 \mathrm{~Hz}, 1 \mathrm{H}), 8.30(\mathrm{~d}, J=7.2 \mathrm{~Hz}, 1 \mathrm{H}), 8.51(\mathrm{~s}, 1 \mathrm{H}), 10.04$ $(\mathrm{d}, J=12.3 \mathrm{~Hz}, 1 \mathrm{H}) ;{ }^{13} \mathrm{C} \mathrm{NMR}\left(75 \mathrm{MHz}, \mathrm{CDCl}_{3}, \delta, \mathrm{ppm}\right) 20.4$, 21.4, 114.4, 116.8, 118.4, 123.7, 125.1, 125.8, 127.4, 128.6, 
$128.8,129.5,133.8,137.7,140.1,140.4,145.3,156.3,156.7$, $179.9,195.2$; HRMS-ESI $(\mathrm{m} / z):[\mathrm{M}-\mathrm{H}]^{-}$calcd for $\mathrm{C}_{26} \mathrm{H}_{19} \mathrm{ClNO}_{3}$, 428.10535; found, 428.10589; Anal. calcd for $\mathrm{C}_{26} \mathrm{H}_{20} \mathrm{ClNO}_{3}$ : C, 72.64; H, 4.69; N, 3.26; found: C, 72.57; H, $4.75 ; \mathrm{N}, 3.31$.

(E)-3-(3-(4-Bromophenylamino)-2-(4-methylbenzoyl)allyl)4H-chromen-4-one (51): Isolated yield $0.384 \mathrm{~g}$ (81\%); colorless solid; mp 223-224 ${ }^{\circ} \mathrm{C}$; ${ }^{1} \mathrm{H}$ NMR $\left(300 \mathrm{MHz}, \mathrm{CDCl}_{3}, \delta\right.$, ppm) 2.40 (s, 3H), $3.70(\mathrm{~s}, 2 \mathrm{H}), 6.90(\mathrm{~d}, J=8.7 \mathrm{~Hz}, 2 \mathrm{H}), 7.21$ (d, $J=8.1 \mathrm{~Hz}, 2 \mathrm{H}), 7.36-7.41(\mathrm{~m}, 3 \mathrm{H}), 7.43-7.52(\mathrm{~m}, 4 \mathrm{H}), 7.69$ (dd, $J=7.5 \mathrm{~Hz}, 1.5 \mathrm{~Hz}, 1 \mathrm{H}), 8.30$ (dd, $J=8.1 \mathrm{~Hz}, 1.8 \mathrm{~Hz}, 1 \mathrm{H})$, $8.51(\mathrm{~s}, 1 \mathrm{H}), 10.04(\mathrm{~d}, J=12.0 \mathrm{~Hz}, 1 \mathrm{H}) ;{ }^{13} \mathrm{C} \mathrm{NMR}(75 \mathrm{MHz}$, $\mathrm{CDCl}_{3}, \delta$, ppm) 20.4, 21.4, 114.5, 114.7, 117.2, 118.4, 123.6, $125.1,125.8,128.6,128.8,132.5,133.8,137.7,140.4,140.6$, 145.1, 156.4, 156.7, 179.9, 195.2; HRMS-ESI $(\mathrm{m} / \mathrm{z}):[\mathrm{M}-\mathrm{H}]^{-}$ calcd for $\mathrm{C}_{26} \mathrm{H}_{19} \mathrm{BrNO}_{3}, 472.05483$; found, 472.05538; Anal. calcd for $\mathrm{C}_{26} \mathrm{H}_{20} \mathrm{BrNO}_{3}$ : C, 65.83; H, 4.25; N, 2.95; found: $\mathrm{C}$, 65.70; H, 4.34; N, 2.91.

(E)-3-(2-(4-Chlorobenzoyl)-3-(phenylamino)allyl)-4Hchromen-4-one (5o): Isolated yield $0.357 \mathrm{~g}(86 \%)$; colorless solid; mp 245-246 ${ }^{\circ} \mathrm{C} ;{ }^{1} \mathrm{H}$ NMR (300 $\mathrm{MHz}, \mathrm{CDCl}_{3}, \delta$, ppm) $3.71(\mathrm{~s}, 2 \mathrm{H}), 7.00-7.05(\mathrm{~m}, 3 \mathrm{H}), 7.26-7.33(\mathrm{~m}, 2 \mathrm{H}), 7.37-7.40$ (m, 2H), 7.44-7.55 (m, 5H), 7.67-7.72 (m, 1H), 8.31 (d, $J=7.8$ $\mathrm{Hz}, 1 \mathrm{H}), 8.50(\mathrm{~s}, 1 \mathrm{H}), 10.08(\mathrm{~d}, J=12.3 \mathrm{~Hz}, 1 \mathrm{H}) ;{ }^{13} \mathrm{C}$ NMR $(75$ $\mathrm{MHz}, \mathrm{CDCl}_{3}, \delta$, ppm) 20.2, 113.7, 115.9, 118.4, 122.9, 123.7, 125.1, 125.9, 128.4, 129.7, 129.9, 133.8, 136.1, 139.2, 141.1, 146.2, 156.2, 156.7, 179.8, 193.8; HRMS-ESI $(\mathrm{m} / \mathrm{z}):[\mathrm{M}-\mathrm{H}]^{-}$ calcd for $\mathrm{C}_{25} \mathrm{H}_{17} \mathrm{ClNO}_{3}$, 414.08970; found, 414.09024; Anal. calcd for $\mathrm{C}_{25} \mathrm{H}_{18} \mathrm{ClNO}_{3}$ : C, 72.20; $\mathrm{H}, 4.36 ; \mathrm{N}, 3.37$; found: $\mathrm{C}$, 72.09; H, 4.24; N, 3.41.

General procedure for the isolation of intermediates 4 . A mixture of the suitable enaminone $2(1 \mathrm{mmol})$ and aniline $\mathbf{3}$ $(1 \mathrm{mmol})$ in DMF $(5 \mathrm{~mL})$ was heated at $130{ }^{\circ} \mathrm{C}$ for $3 \mathrm{~h}$. The reaction progress was monitored by TLC. After completion of the reaction, the solvent was removed and the product was purified by column chromatography with a petroleum ether-ethyl acetate mixture $(4: 1 \mathrm{v} / \mathrm{v})$ as an eluent. Characterization data for compounds $\mathbf{4}$ can be found in Supporting Information File 1.

\section{Supporting Information}

\section{Supporting Information File 1}

Experimental details, full characterization data, detailed structural characterization of compound $\mathbf{5 h}$ and copies of the spectra of all compounds.

[http://www.beilstein-journals.org/bjoc/content/ supplementary/1860-5397-10-43-S1.pdf]

\section{Acknowledgements}

SP and JCM thank the Department of Science and Technology (India) and the Ministerio de Ciencia e Innovación (MICINN, Spain) for the Indo-Spanish collaborative research project, which has made this joint work possible (DST/INT/SPAIN/P11/09 and ACI2009-0956, respectively). The authors acknowledge (i) the DST for granting a major research project to SP (No. SR/S1/OC-50/2011), (ii) the University Grants Commission for the award of a BSR Faculty Fellowship to SP, and (iii) the Ministerio de Economía y Competitividad (MINECO) for the grant CTQ-2012-33272-BQU to JCM. We also thank an anonymous reviewer for bringing reference [62] to our attention.

\section{References}

1. Kumar, R.; Yusuf, M. ARKIVOC 2006, No. ix, 239-264. doi:10.3998/ark.5550190.0007.908

2. Khadem, S.; Marles, R. J. Molecules 2012, 17, 191-206. doi:10.3390/molecules17010191

3. Dyrager, C.; Nilsson Möllers, L.; Kjäll, L. K.; Alao, J. P.; Dinér, P.; Wallner, F. K.; Sunnerhagen, P.; Grøtli, M. J. Med. Chem. 2011, 54, 7427-7431. doi:10.1021/jm200818j

4. Mori, K.; Audran, G.; Monti, H. Synlett 1998, 259-260. doi:10.1055/s-1998-1628

5. Ghani, S. B. A.; Mugisha, P. J.; Wilcox, J. C.; Gado, E. A. M.; Medu, E. O.; Lamb, A. J.; Brown, R. C. D. Synth. Commun. 2013, 43, 1549-1556. doi:10.1080/00397911.2011.647222

6. China Raju, B.; Rao, R. N.; Suman, P.; Yogeeswari, P.; Sriram, D.; Shaik, T. B.; Kalivendi, S. V. Bioorg. Med. Chem. Lett. 2011, 21, 2855-2859. doi:10.1016/j.bmcl.2011.03.079

7. Bhat, A. S.; Whetstone, J. L.; Brueggemeier, R. W. Tetrahedron Lett. 1999, 40, 2469-2472. doi:10.1016/S0040-4039(99)00279-8

8. Wu, E. S. C.; Cole, T. E.; Davidson, T. A.; Blosser, J. C.; Borrelli, A. R.; Kinsolving, C. R.; Milgate, T. E.; Parker, R. B. J. Med. Chem. 1987, 30, 788-792. doi:10.1021/jm00388a007

9. Pietta, P.-G. J. Nat. Prod. 2000, 63, 1035-1042. doi:10.1021/np9904509

10. Bennett, C. J.; Caldwell, S. T.; McPhail, D. B.; Morrice, P. C.; Duthie, G. G.; Hartley, R. C. Bioorg. Med. Chem. 2004, 12, 2079-2098. doi:10.1016/j.bmc.2004.02.031

11. Krishnamachari, V.; Levine, L. H.; Zhou, C.; Pare, P. W. Chem. Res. Toxicol. 2004, 17, 795-804. doi:10.1021/tx034242z

12. Kumar, M.; Kumar, S.; Kaur, S. Afr. J. Pharm. Pharmacol. 2011, 5, 421-427.

13. Khan, I. A.; Avery, M. A.; Burandt, C. L.; Goins, D. K.; Mikell, J. R.; Nash, T. E.; Azadegan, A.; Walker, L. A. J. Nat. Prod. 2000, 63, 1414-1416. doi:10.1021/np000010d

14. Kim, H. P.; Son, K. H.; Chang, H. W.; Kang, S. S. J. Pharm. Sci. 2004, 96, 229-245. doi:10.1254/jphs.CRJ04003X

15. Middleton, E.; Kandaswami, C.; Theoharides, T. C. Pharmacol. Rev. 2000, 52, 673-751.

16. Wang, Y.-B.; Huang, R.; Zhang, H.-B.; Li, L. J. Asian Nat. Prod. Res. 2006, 8, 663-670. doi:10.1080/10286020500246303

17. Lin, C.-N.; Kuo, S.-H.; Chung, M.-I.; Ko, F.-N.; Teng, C.-M. J. Nat. Prod. 1997, 60, 851-853. doi:10.1021/np970011e 
18. Bauvois, B.; Puiffe, M.-L.; Bongui, J.-B.; Paillat, S.; Monneret, C.; Dauzonne, D. J. Med. Chem. 2003, 46, 3900-3913. doi:10.1021/jm021109f

19. Quintin, J.; Roullier, C.; Thoret, S.; Lewin, G. Tetrahedron 2006, 62, 4038-4051. doi:10.1016/j.tet.2006.02.024

20. Maicheen, C.; Jittikoon, J.; Vajragupta, O.; Ungwitayatorn, J. Med. Chem. 2013, 9, 329-339. doi:10.2174/1573406411309030003

21. Dyrager, C.; Friberg, A.; Dahlén, K.; Fridén-Saxin, M.; Börjesson, K.; Wilhelmsson, L. M.; Smedh, L.; Grøtli, M.; Luthman, K. Chem.-Eur. J. 2009, 15, 9417-9423. doi:10.1002/chem.200900279

22. Ellis, G. P. Chromenes, Chromanones and Chromones; John Wiley and Sons: New York, 1977.

23. Ibrahim, M. A.; Ali, T. E.; Alnamer, Y. A.; Gabr, Y. A. ARKIVOC 2010, No. i, 98-135. doi:10.3998/ark.5550190.0011.103

24. Pinto, D. C. G. A.; Silva, A. M. S. Curr. Org. Chem. 2012, 9, 561-572. doi:10.2174/157017912802651429

25. Lue, P.; Greenhill, J. V. Adv. Heterocycl. Chem. 1996, 67, 207-343. doi:10.1016/S0065-2725(08)60072-0

26. Elassar, A.-Z. A.; El-Khair, A. A. Tetrahedron 2003, 59, 8463-8480 doi:10.1016/S0040-4020(03)01201-8

27. Govindh, B.; Diwakar, B. S.; Murthy, Y. L. N. Org. Commun. 2012, 5, 105-119.

28. Bernini, R.; Fabrizi, G.; Sferrazza, A.; Cacchi, S. Angew. Chem., Int. Ed. 2009, 48, 8078-8081. doi:10.1002/anie.200902440

29. Yang, J.; Wang, C.; Xie, X.; Li, H.; Li, Y. Eur. J. Org. Chem. 2010, 4189-4193. doi:10.1002/ejoc.201000607

30. Mahata, P. K.; Venkatesh, C.; Syam Kumar, U. K.; Ila, H.; Junjappa, H. J. Org. Chem. 2003, 68, 3966-3975. doi:10.1021/jo034053।

31. Yan, R.-L.; Luo, J.; Wang, C.-X.; Ma, C.-W.; Huang, G.-S.; Liang, Y.-M. J. Org. Chem. 2010, 75, 5395-5397. doi:10.1021/jo101022k

32. Schirok, H.; Alonso-Alija, C.; Benet-Buchholz, J.; Göller, A. H.; Grosser, R.; Michels, M.; Paulsen, H. J. Org. Chem. 2005, 70, 9463-9469. doi:10.1021/jo0515428

33. Tenti, G.; Egea, J.; Villarroya, M.; León, R.; Fernández, J. C.; Padín, J. F.; Sridharan, V.; Ramos, M. T.; Menéndez, J. C. Med. Chem. Commun. 2013, 4, 590-594. doi:10.1039/c3md20345j

34. Rocchi, D.; González, J. F.; Menéndez, J. C. Green Chem. 2013, 15, 511-517. doi:10.1039/c2gc36221j

35. Estévez, V.; Villacampa, M.; Menéndez, J. C. Chem. Commun. 2013, 49, 591-593. doi:10.1039/c2cc38099d

36. Tenti, G.; Ramos, M. T.; Menéndez, J. C. ACS Comb. Sci. 2012, 14, 551-557. doi:10.1021/co300081k

37. Maiti, S.; Menéndez, J. C. Chem. Commun. 2011, 47, 10554-10556. doi:10.1039/c1cc11246e

38. Maiti, S.; Sridharan, V.; Menéndez, J. C. J. Comb. Chem. 2010, 12, 713-722. doi:10.1021/cc100084b

39. Suryavanshi, P. A.; Sridharan, V.; Menéndez, J. C. Org. Biomol. Chem. 2010, 8, 3426-3436. doi:10.1039/c004703a

40. Sridharan, V.; Maiti, S.; Menéndez, J. C. J. Org. Chem. 2009, 74, 9365-9371. doi:10.1021/jo9021309

41. Sridharan, V.; Maiti, S.; Menéndez, J. C. Chem.-Eur. J. 2009, 15, 4565-4572. doi:10.1002/chem.200900044

42. Sridharan, V.; Menéndez, J. C. Org. Lett. 2008, 10, 4303-4306. doi:10.1021/ol801738d

43. Prasanna, P.; Balamurugan, K.; Perumal, S.; Menéndez, J. C. Green Chem. 2011, 13, 2123-2129. doi:10.1039/c0gc00952k

44. Rajesh, S. M.; Bala, B. D.; Perumal, S.; Menéndez, J. C. Green Chem. 2011, 13, 3248-3254. doi:10.1039/c1gc15794a
45. Indumathi, S.; Perumal, S.; Menéndez, J. C. Tetrahedron 2011, 67, 7101-7105. doi:10.1016/j.tet.2011.06.107

46. Bala, B. D.; Balamurugan, K.; Perumal, S. Tetrahedron Lett. 2011, 52, 4562-4566. doi:10.1016/j.tetlet.2011.06.102

47. Balamurugan, K.; Jeyachandran, V.; Perumal, S.; Menéndez, J. C. Tetrahedron 2011, 67, 1432-1437. doi:10.1016/j.tet.2010.12.052

48. Kumar, R. S.; Osman, H.; Perumal, S.; Menéndez, J. C.; Ali, M. A.; Ismail, R.; Choon, T. S. Tetrahedron 2011, 67, 3132-3139. doi:10.1016/j.tet.2011.02.058

49. Balamurugan, K.; Perumal, S.; Menéndez, J. C. Tetrahedron 2011, 67, 3201-3208. doi:10.1016/j.tet.2011.03.020

50. Indumathi, S.; Perumal, S.; Menéndez, J. C. J. Org. Chem. 2010, 75, 472-475. doi:10.1021/jo9021327

51. Balamurugan, K.; Perumal, S.; Reddy, A. S. K.; Yogeeswari, P.; Sriram, D. Tetrahedron Lett. 2009, 50, 6191-6195. doi:10.1016/j.tetlet.2009.08.085

52. Indumathi, S.; Kumar, R. R.; Perumal, S. Tetrahedron 2007, 63, 1411-1416. doi:10.1016/j.tet.2006.11.093

53. Srinivasan, M.; Perumal, S. Tetrahedron 2007, 63, 2865-2874. doi:10.1016/j.tet.2007.01.038

54. Karthikeyan, S. V.; Perumal, S. Tetrahedron Lett. 2007, 48, 2261-2265. doi:10.1016/j.tetlet.2007.01.168

55. Muthusaravanan, S.; Perumal, S.; Almansour, A. I. Tetrahedron Lett. 2012, 53, 1144-1148. doi:10.1016/j.tetlet.2011.12.097

56. Cambridge Crystallographic Database, CCDC number 894829.

57. Pletnev, A. A.; Tian, Q.; Larock, R. C. J. Org. Chem. 2002, 67, 9276-9287. doi:10.1021/jo026178g And references cited therein.

58. Marx, G. S. J. Org. Chem. 1971, 36, 1725-1726. doi:10.1021/jo00811a044

59. Zawisza, A. M.; Muzart, J. Tetrahedron Lett. 2007, 48, 6738-6742. doi:10.1016/j.tetlet.2007.07.077

60. Kim, H. S.; Gowrisankar, S.; Kim, S. H.; Kim, J. N. Tetrahedron Lett. 2008, 49, 3858-3861. doi:10.1016/j.tetlet.2008.04.080

61. Liu, B.; Zheng, G.; Liu, X.; Xu, C.; Liu, J.; Wang, M. Chem. Commun. 2013, 49, 2201-2203. doi:10.1039/c3cc37571d

62. Ai, K.; Liu, Y.; Lu, L.; Cheng, X.; Huo, L. J. Mater. Chem. 2011, 21 , 3365-3370. doi:10.1039/c0jm02865g

\section{License and Terms}

This is an Open Access article under the terms of the Creative Commons Attribution License (http://creativecommons.org/licenses/by/2.0), which permits unrestricted use, distribution, and reproduction in any medium, provided the original work is properly cited.

The license is subject to the Beilstein Journal of Organic Chemistry terms and conditions: (http://www.beilstein-journals.org/bjoc)

The definitive version of this article is the electronic one which can be found at:

doi:10.3762/bjoc. 10.43 